\section{University of Leeds : Appointments}

THE following appointments in the University of Leeds are announced: Dr. G. R. Tristram, as professor of leather industries from October 1 ; Dr. M. Atkinson, as lecturer in the Department of Medicine; Mr. W. C. Gregory, as lecturer in geology from September 1; Mr. I. R. McDougall, as lecturer in chemical engineering from September 1 ; Mr. F. O'M. Shiel, as lecturer in pathology; Mr. R. W. Spencer, as lecturer in chemical pathology from August 1; Dr. R. J. Williams (at present Turner and Newall research fellow in the Department of Physical Chemistry) as Brotherton research lecturer in physical chemistry for one year from October 1.

Donations to the University building fund have now brought the total amount in the fund to $£ 497,828$.

\section{University of London: Appointments}

THE following appointments in the University of London are announced: Dr. John Brown, lecturer in University College, to the University readership in electrical engineering tenable at that College; Dr. J. A. Clegg, senior lecturer in physics at the Imperial College of Science and Technology, to the University readership in physics; Dr. Henry Elliot, senior lecturer in physics at the Imperial College of Science and Technology, to the University readership in physics ; and Dr. Robert Latham, senior lecturer in physics at the Imperial College of Science and 'Technology, to the University readership in high temperature physics, all tenable at that College.

\section{The Night Sky in June}

FULL moon occurs on June 12d. 10h. 02m. U.T., and new moon on June $27 \mathrm{~d}$. $20 \mathrm{~h}$. $53 \mathrm{~m}$. The following conjunctions with the Moon take place: June ld. 09h., Mars $6^{\circ}$ N.; June 6d. 01h., Jupiter $6^{\circ}$ N.; June 1ld. 14h., Saturn $0.0^{\circ} \mathrm{S}$.; June 30d. 00h., Mars $6^{\circ} \mathrm{N}$. In addition to these conjunctions with the Moon, Mars is in conjunction with Pollux on June 1ld. 06h., Mars being $5 \cdot 5^{\circ} \mathrm{S}$., Mercury with Aldebaran on June 18d. 13h., Mercury being $4.2^{\circ}$ N., and Venus with Pollux on June 26d. 04h., Venus being $5 \cdot 4^{\circ} \mathrm{S}$. Mercury rises a short time before the Sun, but observation will be difficult. Venus sets rather more than an hour after the Sun, and is visible as a bright object low in the west just after sunset. Mars is visible in the west for a short time after sunset, its stellar magnitude being $+2 \cdot 0$. Jupiter sets at $1 \mathrm{~h} .15 \mathrm{~m} ., 0 \mathrm{~h}$. $20 \mathrm{~m}$. and $23 \mathrm{~h}$. $25 \mathrm{~m}$. at the beginning, middle and end of the month, respectively; it passes from Leo into Virgo on June 11. Its stellar magnitude is $\mathbf{- 1 \cdot 6}$, and its distance from the Earth in the middle of the month is 500 million miles. Saturn sets at $4 \mathrm{~h} .10 \mathrm{~m}$., $3 \mathrm{~h}$. $10 \mathrm{~m}$. and $2 \mathrm{~h} .05 \mathrm{~m}$. on June 1,15 and 30 , respectively; it is retrograding in Ophiuchus, and is north of Antares. The stellar magnitude of Saturn is $+0 \cdot 2$ and its distance from the Earth on June 15 is 840 million miles. There is one occultation of a star brighter than magnitude 6 , observation being made at Greenwich: June 11d. 0h. $25 \cdot 7 \mathrm{~m}$., $\omega^{1}$ Sco. $(D) ; D$ refers to disappearance. The summer solstice occurs on June 2ld. $16 \mathrm{~h}$.

\section{Announcements}

Mr. J. R. V. DoLPhiN, who has been chief engineer to the Weapons Group of the United Kingdom Atomic Energy Authority since 1951, has been appointed chief engineer to the Authority's Research Group.
$\mathrm{He}$ will take up his new duties at Harwell on August 1.

Dr. I. Bernard Cohen, associate professor of the history of science and of general education at Harvard University, will deliver a lecture on June 13 at 4.15 p.m. in the Clarendon Laboratory, Oxford, on "Wave and Corpuscular Theories of Light from Newton to Maxwell".

Aт a recent meeting of the Nutrition Society the following officers were elected: President, Dame Harriette Chick; Hon. Secretary, Dr. R. J. L. Allen (Beecham Foods, Ltd., Brentford, Middlesex) ; Hon. Treasurer, Dr. W. F. J. Cuthbertson; Hon. Editor, Dr. S. K. Kon; Hon. Programmes Secretary, Miss .D. F. Hollingsworth. Dr. G. H. Bourne and Dr. A. J. Amos retired after five years service as hon. secretary and hon. treasurer, respectively.

The award of the Corday-Morgan Medal and Prize, consisting of a silver medal and a prize of 200 guineas, is made annually to the chemist of either sex and of British nationality who, in the judgment of the Council of the Chemical Society, has published during the year in question the most meritorious contribution to experimental chemistry, and who has not, at the date of publication, attained the age of thirty-six years. Copies of the rules governing the award can be obtained from the General Secretary of the Chemical Society, Burlington House, London, W.l. Applications or recommendations in respect of the award for 1956 must be received not later then December 31,1957 , and applications for the award for 1957 are due before the end of 1958 .

THE 363rd meeting of the Biochemical Society will bo held in the Department of Chemistry of King's College, Newcastle upon Tyne, on June 28, starting at 11.15 a.m.

A JoINT meeting on "The Control of Chemical Additives in Food" of the Food Law Institute of the United States, the Food Group of the Society of Chemical Industry, the Society for Analytical Chemistry and the Association of Public Analysts, of Great Britain, is to be held at the Royal Institution, London, on July 26. Further details can be obtained from the Society for Analytical Chemistry, 14 Bel. grave Square, London, S.W.1.

The Nutrition Society is to hold a symposium on "Flour and Bread" in the Anatomy School at Cambridge on July 5 and 6 . The chairman will be Sir Rudolph Peters (Biochemistry Department, Institute of Animal Physiology, Babraham, Cambridge) and the following contributions have been arranged: Dame Harriette Chick (Cambridge): "Wheaten Bread : a Historical Sketch"; Dr. C. R. Jones (St. Albans): "Essentials of the Flour Milling Process"; Dr. E. M. Widdowson (Cambridge): "Problems and Pleasures of Human Experiments"; Prof. R. A. Morton (Liverpool) : "The Report of the Panel on Flour"; Dr. H. M. Sinclair (Oxford): "Nutritional Aspects of High-extraction Flour"; Dr. D. W. Kent-Jones (London): "The Case for Fortified White Flour"; Dr. J. R. Nicholls and Mr. J. R. Fraser (London): "Analytical Problems in the Determination and Control of Extraction Rates". Further particulars can be obtained from the Hon. Programmes Secretary of the Nutrition Society, Miss D. F. Hollingsworth, e/o Ministry of Agriculture, Fisheries and Food, Great Westminster House, Horseferry Road, London, S.W.1. 